\title{
Strategic Representation of an Abstract Reality: Spiraling Relations between Organizational Culture and Innovativeness
}

\author{
A. Emre Demirci ${ }^{1}$ \\ ${ }^{1}$ Management \& Organization Department, Faculty of Economics \& Administrative Sciences, Anadolu University, \\ Eskisehir, Turkey \\ Correspondence: Asst. Prof. Dr. A. Emre Demirci, Management \& Organization Department, Faculty of Economics \\ \& Administrative Sciences, Anadolu University, Eskisehir, Turkey. E-mail: aedemirci@anadolu.edu.tr \\ Received: October 17, 2012 \\ Accepted: July 17, 2013 \\ Online Published: August 1, 2013 \\ doi:10.5430/jms.v4n3p39 \\ URL: http://dx.doi.org/10.5430/jms.v4n3p39
}

\begin{abstract}
Innovation is still one of the most debated topics among the academics and business professionals. The question of how organizations innovate captures attention from many disciplines and leads to extensive amount of research. Although there are many variables that affect an organization's innovative performance, organizational culture can be considered as a key issue as it is strongly associated with the values, attitudes, behaviors and organizational practices. As organizations have different cultural profiles and, in many cases, competing cultural values exist within the organization simultaneously, it is difficult to build one-dimensional linkages about the relations between organizational culture and innovativeness.

This study aims to analyze the relations between innovativeness and four different organizational cultures including team, entrepreneurial, hierarchical and rational cultures. A sample of 371 surveys was collected from five leading companies operating in the chemicals industry in Eskisehir, Turkey.
\end{abstract}

Keywords: organizational culture, innovativeness, innovation

\section{Introduction}

Innovativeness is now firmly recognized as one of the most crucial issues for economic survival and sustainability for almost any type of business. Constantly changing structure of rivalry, diversifying customer needs, shrinking markets and efforts towards sustainability are among the factors forcing businesses to continuously innovate their products/services, processes and organizational structures.

Especially, in the last three decades, rules of the game have changed dramatically and previous parameters of competition such as production capacity, quality, cost control and speed have become insufficient to help businesses to survive in the long run. Although these competitive parameters were not totally abandoned, another challenging parameter - innovation - has dominated the business world today.

Based on the above discussions, we must say that innovation is a key factor for the sustainable success for the businesses. In addition to this reality, companies' innovation efforts should be constant rather than a one-time action. Thus, businesses should constantly innovate their products/services, processes and organizational structures for a long term survival. Considering the fact that many innovations are imitated or replaced by the rivals within several months, we must accept that basing the future of the business on one single innovation would most likely result with a fatal failure.

Oslo Manual (OECD, 2005) defines innovation as;

“...Implementation of a new or significantly improved product (good or service), or process, a new marketing method, or a new organizational method in business practices, workplace organization or external relations."

Based on the definition above, it is important to stress some points directly related with innovation. First of all, we can say that innovations can be done not only in products and services but also processes and organizational structures. Another important point is about the context of innovation. Innovation is not only about totally being totally new but also about significant degree of improvement. Although it is not clearly found in this definition, there is another important factor that needs to be mentioned. Many further definitions agree that innovations should necessarily have a commercial identity. Audretsch and Acs (1991) define innovation as the commercial introduction of a new product, process or service. 
Especially the last two issues we have mentioned above differentiate between innovation and inventions. Stressing the differences between these two concepts is very important as in many cases they are used interchangeably.

First of all while inventions are always totally new by its nature, innovations can be significant improvements. Day (2002) argues that more less than 10 percent of all innovations are radical innovations which means that vast majority of innovations are actually improvements at different levels.

If we represent innovation with an equation, then it would be a represented with a combination of creativity, invention/improvement and commercialization. We can easily say that these three aspects are the major pillars of innovation. Any missing pillar would inevitably result in a failure in innovation efforts (Figure 1).

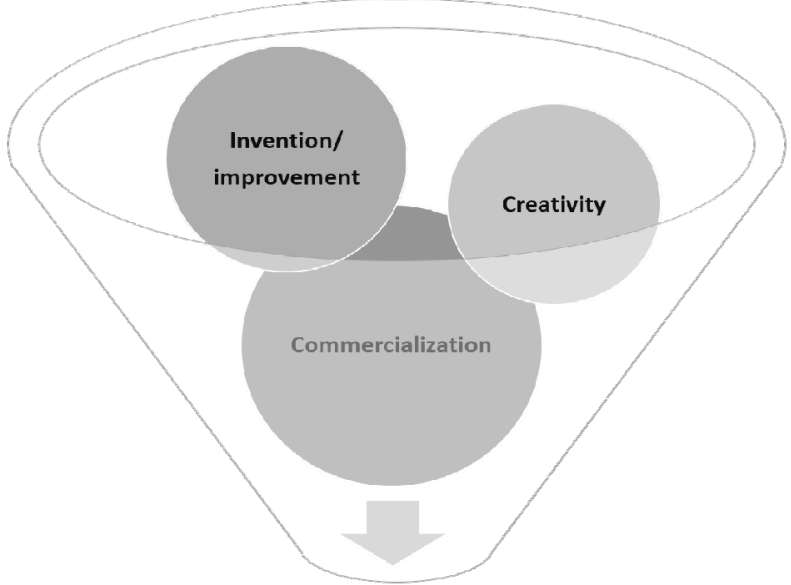

INNOVATION

Figure 1. Three pillars of innovation

Among these pillars, creativity is of paramount importance. Creativity is the initial step in the innovation process and also a more abstract issue compared to the other pillars of innovation. Malagueno and Bisbe (2010) define organizational creativity as the organization's capability of generating valuable and functional ideas, procedures, and products/services by individuals working together in a complex organizational setting. It is very crucial to address that individuals are at the heart of this process and thus could be considered as the primary source of creativity and innovation within the organization. On the other hand, characteristics of the organization have impact on individuals' and groups' creativity. Kanter (1996) suggests that organizational culture is an important contextual factor that influences creativity at individual level. Similarly, Amabile et al. (1996) claim that organizational culture is among the organizational characteristics that are associated with creative behavior within the organization. Creativity is a factor that is embedded in the organizational culture and the nature of organizational culture can have various effects on creative processes. It can either be a driving force behind creativity or in some cases it can be a barrier that hinders individuals to reveal their creative capacity.

In addition to creativity there are other factors that are related with innovation. Origins of innovation can vary dramatically. Innovation may result from pressure, necessity or even adverse conditions. It can even result from a fear of failure which is sometimes a more powerful motive than the hope to be successful (Porter, 1991; Claver et al., 1998).

These issues require an in-depth analysis of the major dimensions of organizational culture and how they interact with the innovation processes within the organization. As both organizational culture and innovation are the key issues for a long term survival, it is important to analyze how these key factors interact with each other. Specifically, we can argue that organizational culture has long been recognized as a key determinant in the field of innovation and therefore it requires to be better understood to nurture innovation in a more structured and systematic manner (Lemon \& Sahota, 2004).

In the broader sense, Denison (1990) defines organizational culture as "the underlying values, beliefs and principles that serve as foundation for organization's management system, as well as the set of management practices and behaviors that both exemplify and reinforce those basic principles". As it was clearly stated in the definition, organizational culture deals with values, beliefs, principles and behaviors that shapes the management system. According to Schein (1985), organizational culture guides individuals' beliefs, thoughts, perceptions and feelings and ultimately directs their behaviors. Foster-Fishman and Keys' (1997) study claims that organizational culture 
considers individual attitudes, employee behavior, and organizational practices as interconnected elements within organizational life. Bartunek and Moch (1987) suggest that these traditions live in and guided by the individuals' interpretative frames and the organizational practices that stem from these perceptions.

Any type of change effort including innovation is most likely to achieve desired results when they are compatible with the organizational culture. For example, we can argue that innovative products/services, processes and organizational structures are partially result from in-depth market and technical knowledge-bases that individuals within the organization possess and share. Thus, sharing of this type of tacit and explicit knowledge contributes to the innovation process (Ozdemir \& Demirci, 2012). Constant, Kiesler and Sproull (1994) suggest that attitudes and norms within the organization can support or constrain knowledge sharing. As attitudes and norms are clearly integral aspects of organizational culture, we can argue that along with the organizational policies and individual factors, organizational culture influences attitude towards knowledge sharing. As given in the example above, there are many other aspects related with organizational culture that affects innovation processes.

\section{Organizational Culture and Innovativeness}

Based upon the previous discussions, we claim that many facets of organizational culture have direct impact on the innovation performance of an organization. Post-industrial organizations today are mostly knowledge-based and their survival heavily depends on creativity and innovation (Read, 1996; Tödtling, Lehner \& Kaufmann, 2009). This reality is forcing business leaders to create an organizational environment whereby creativity and innovation would be embedded in the cultural structure and the norms. Tushman and O'Reilly (2006) suggest that many successful organizations are those capable of absorbing creativity and innovation into their organizational culture and management practices. They refer organization culture as a crucial and strategic ingredient for winning through innovation.

Martins and Terblanche (2003) note that the basic elements such as shared values, beliefs and behaviors influence creativity and innovation in two different ways:

i. Socialization process within the organization teaches individuals what behavior is acceptable and how activities should be done. Through this process, norms are developed, accepted and shared. In accordance with these norms, individuals build assumptions whether innovation is encouraged or supported by the organization and whether it is considered to be an integral part of the organization. In return, these assumptions shape their perceptions, attitudes and behaviors towards creativity and innovation.

ii. Values, assumptions, beliefs as major elements of organizational culture shape behaviors and activities. They are also materialized as solid organizational aspects such as structures, policies, management practices and procedures. These materialized factors have direct impact on the creative and innovative activities within the organization.

Parallel with these discussions, Hartmann (2006) claims that if innovation is accepted as a core value of the organization, individuals within the organization will most likely to behave accordingly. Such an environment can promote creative and innovative behavior among the members of the organization and increase commitment to innovative actions.

Organizations have to meet some requirements regarding their internal behavior and their external relationships if they want to be successful in innovation and if they want to adopt technological progress (Tylecote, 1996). Although there are numerous requirements closely linked with an organizational culture that supports innovation, researchers found some leading organizational characteristics found in innovative organizations. Hurley and Hult (1998) found that there are some cultural characteristics associated with an innovative organization. Their research revealed that market focus, emphasis on individual learning and development, status differential, participative decision making, support and collaboration, power sharing and empowerment, comprehensive communication and finally tolerance for conflict and risk taking are among the major cultural characteristics attributed to innovative organizations. Shane (1993) claim that organization-level values such as tolerance for risk and change, autonomy, independence, freedom and power sharing drive innovation within the organizations. On the other side of the coin, lack of these organizational characteristics and inadequate emphasis on innovation in the organizational values will not result with intended behaviors among the members of the organization that in return causes organization to fail in its innovation efforts.

These discussions lead us to a conclusion that organizational culture can either support or constrain creativity and innovation and different organizational cultures have different effects on the creative and innovative performance of the organization.

From this perspective, our study primarily focuses on different organizational culture profiles and their relations with innovativeness instead of considering various individual values embedded in the organizational culture. Thus, we 
aim to address the relations between organizational culture and innovativeness from a broader perspective. We will focus on four different type of archetypal organizational cultures including entrepreneurial, hierarchical, team and rational. This classification is based on the competing values framework originally developed by Quinn and Rohrbaugh (1981). Model offers a conceptual framework about organizational effectiveness which they define as value-based judgment about the performance of the organization. Central point of the competing values framework is that the effectiveness of the organization depends on the organization's ability to satisfy multiple performance criteria based on four value sets depicted in two dimensions (Dastmalchian, Lee \& $\mathrm{Ng}$, 2000). In the model, Quinn and Rohrbaugh (1981) suggested four sets of competing values in two dimensions whereby the sets suggest a polar opposite model with contrasting emphases (Quinn \& Rohrbaugh, 1983). Cameron and Quinn (2011) also suggest that competing values framework could be adopted as a general framework for research in organizational studies. Issues about organizational culture can be addressed in this research domain through a perspective suggested by competing values framework model.

As mentioned above competing values framework conceptualizes the major differences between organizational cultures in two dimensions. These dimensions are structure and focus. While structure dimension ranges from flexibility to control, focus dimension ranges from internal organizational factors to factors external to organization. Structure dimension focuses on the differences between the organizations in terms of their approach to flexibility and control. While some organizations tend to have more consistent behavioral patterns, others tend to empower their employees to make their own decisions. Internal organizational factors as a sub-dimension of the focus dimension refer to organizational factors such as employee satisfaction while factors external to the organization address organization's capability to adapt itself to the constantly changing environment (Gregory et al., 2009).

Figure 2 shows the dimensions and the sub-dimensions or quadrants conceptualizing competing values framework based on different organizational cultures. Each quadrant on the figure competes with or contradicts to the quadrant on the diagonal (Dastmalchian, Lee \& Ng, 2000).

Top left quadrant shows the team culture emphasizing internal and flexible values such as investment in people, mutual support, working together in harmony. Similarly, top right quadrant represents entrepreneurial culture emphasizing flexible and external values such as dynamism, creativity, entrepreneurship, risk taking, lower risk ambiguity and long-term commitment to growth and acquiring new resources.

Bottom left quadrant shows hierarchical culture emphasizing internal and control-based values such as formalization, centralization, managing by procedures, stability and efficiency of operations. Finally, bottom right quadrant represents rational culture emphasizing external and control-based values. Organizations in this quadrant focus majorly on getting the job done. Competition among the members of the organization and goal orientation are crucial values. Finally, for this quadrant, long term focus is maintaining competitive edge and achieving defined goals and targets. Market share and market penetration are the major indicators of success (Cameron \& Queen, 2011).

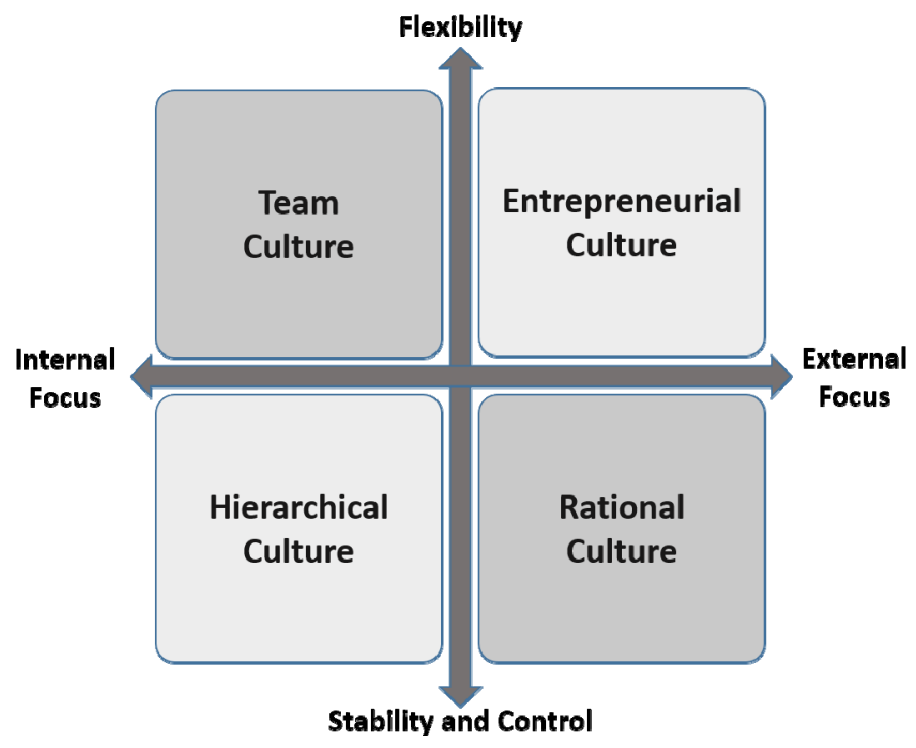

Figure 2. Competing values framework model for organizational cultures

Source: Adapted from Cameron and Freeman (1991) 
In this study, organizational culture profiles mentioned above were taken into consideration within competing values framework perspective and how these profiles affect innovativeness is addressed. Innovativeness as an organizational characteristic is affected by the different organizational cultures discussed above. However, there is need to further examine how and to what extent innovativeness is affected by each individual cultural archetype.

\subsection{Innovativeness and Team Culture}

Team culture is an organizational culture archetype that primarily emphasizes concern for people within the organization. Innovative ideas mainly stem from the complex interaction of diverse ideas and perspectives (Sethi, Smith \& Park, 2001). Sethi et al. (2001) also note that likelihood of having innovative ideas improves as the diversity of input increases. According to Morariu, Serghiuta and Chasovschi (2009), team culture refers to the collective effort of all employees for the common goals while promoting creativity and communication. They suggest that innovation and creativity are encouraged within the organizations having a strong team culture. Similarly, Katzenbach and Smith (1992) argue that organizations most likely fail to meet the challenges ahead - including innovation - without a team culture.

Team culture heavily depends on empowering the members of the organizations to make their own decisions. Dennison and Mishra (1995) identified four cultural traits and values that are closely associated effectiveness in organizational efforts. One of their main cultural values is the involvement of employees. They suggest that involvement creates a sense of ownership among the members of the organization that in return improves commitment to the organization. As a result of this strong commitment, individuals improve their capacity to operate under higher uncertainty. Enhanced capacity to work effectively under such conditions is an important factor to succeed in innovation efforts.

However, there is a fine line between a team culture and a clan culture. Although clan culture is also based on socialization and internalization of organizational values and norms, these processes are considered within a hierarchy-based control system (Ouchi \& Wilkins, 1985). Kerr and Slocum (1987) note that individuals within the organization are like the members of a fraternity and they share a sense of pride of being a part of this group. Pressure to conform is heavily felt in the organization. Supporting this point of view, as a result of his study of teams in a small manufacturing company, Barker (1993) found that team members built a clan value system that created a bureaucratic control system even more powerful than they had previously. Barker (1993) defines this process as "tightening the iron cage" by transferring control from formal mechanisms to team's values and norms. This is a paradox that any organization can encounter while trying to liberate the working environment. Kerr and Slocum (1987) also suggest that clan culture does not usually encourage risk taking and innovation. Consequently, based on this point of view, clan culture does not usually support entrepreneurial activities in the organization. Thus, clan culture may be ineffective in an environment where innovation, aggressiveness and strong desire for individual achievement are integral to achieve and maintain success.

Based on the discussions above, we can argue that whether the dominant culture in the organization is team or clan would make difference in terms of innovative performance. As opposed to a clan culture, team culture that creates diverse ideas and encourages exchange of these diverse ideas among the members can foster innovation and creativity. Many relevant researches revealed that there is a solid link between the team-based organization structure and innovative performance (Hise et al., 1990; Hoegl \& Proserpio, 2004).

Also, effective use of teams can break down the departmental barriers and enhance the flow of information between organizational units that in return facilitates innovation process. Cross-functional teams could be adopted to deal with the problems associated with lack of information sharing between departments and individuals - especially those from different backgrounds.

\subsection{Innovativeness and Entrepreneurial Culture}

Innovation and entrepreneurship has long been accepted as concepts highly correlated with each other. We can argue that entrepreneurial organizations are those outperform their rivals through their innovative skills and capabilities. Organizations with an entrepreneurial culture emphasize entrepreneurship, creativity, adaptability, risk tolerance, flexibility and growth through acquiring new resources. McGuire (2003) defines entrepreneurial organizational culture as:

"A system of shared values, beliefs and norms of members of an organization, including valuing creativity and tolerance of creative people, believing that innovating and seizing market opportunities are appropriate behaviors to deal with problems of survival and prosperity, environmental uncertainty, and competitors' threats, and expecting organizational members to behave accordingly." 
In their competitive values framework model, Cameron and Queen (2011) places organizations with entrepreneurial culture to the top right quadrant that represents a focus on flexibility and factors external to the organization. Based on this perspective, we can suggest that entrepreneurial culture is an outward culture that aims to align organization with the external environment through constant innovative and entrepreneurial activities. Deshpande and Farley (1999) also suggest that entrepreneurial organizational culture, by nature, emphasizes risk taking and innovation. According to Covin and Miles (1999), innovation is the only dimension that has to be possessed by the entrepreneurial organizations. They also claim that organizations that fail to innovate cannot be considered as entrepreneurial organizations at firm level albeit they meet other criteria such as proactiveness and risk taking. In order to support their innovation capability, entrepreneurial organizational cultures also reward timeliness, speed and flexibility (Siegel, Waldman \& Link, 2003). In their research, Jun and Shin (1995) found that senior executives in the entrepreneurial cultures lean towards showing more innovative leadership styles. Supporting this point of view, Lumpkin and Dess (1996) suggest that entrepreneurial organizational culture reflects a tendency to encourage experimentation and creative processes often departing from conventional and established organizational practices. Therefore, business leaders should provide the members of the organization with opportunities to explore, investigate and experiment in order to create an organizational culture that fosters innovative behavior. In an entrepreneurial culture, employees tend to identify opportunities and risks based on their perceptions about internal and external organizational environment and bring critical resources together to engage in innovative and creative ventures (Abok et al., 2013).

\subsection{Innovativeness and Hierarchical Culture}

In their competitive values framework model, Cameron and Queen (2011) places organizations with hierarchical culture to the bottom left quadrant that represents a focus on internal and control-based values such as formalization, management by procedures and stability. Cameron and Freeman (1991) suggest that order, rules, regulations, uniformity and efficiency are the dominant attributes in an organization with a hierarchical culture. They also indicate that the strategic priority and emphases for such organizations focus on stability, predictability and smooth operations. Formalization and centralization are among the primary factors associated with hierarchical culture. The degree of hierarchy of authority is a conventional measure of centralization within the organization (Van de Ven, 1976) and centralization tends to be more evident in the organizations where highly formal practices exist (Demirci, 2013).

Although many studies suggest that the rules and regulations, excessive use of authority and centralization hinder the innovative efforts of the organizations, we claim that the relations between formalization, centralization and innovation are multidimensional.

Fiol and Lyles (1985) suggest that organizations with a hierarchical culture would most likely to resist change initiatives and less likely to have motives to adapt themselves to the changing environment as they have strong emphasis on stability and control. Their research also revealed that organizational cultures that limit bureaucracy and hierarchical values are most likely to lead to higher absorptive capacity. Similarly, Wildawsky and Dake (1990) suggest that excessive normative constraints and control on behavior that are typical characteristics of hierarchical cultures are perceived as barriers to autonomy of the individuals. Such an environment tends to damage the innovation processes within the organization. Burns and Stalker (1961) note that organic organizational systems are more likely to succeed in innovation efforts compared to mechanical organizational systems that refer to tightly controlled and rigid organizational structures. According to their approach, narrow span of control, rigid specialization on tasks, lack of autonomy and high centralization are among the characteristics that describe mechanistic organizational structures.

On the other hand, recent studies have revealed some conflicting results with the previous studies. For example Damanpour (1991) suggests that initiation and implementation of innovations are two different discussions. According to Damanpour's research findings, organic structures representing a diverse and a more autonomous organizations tend to initiate more innovations. However, organizations with mechanistic values implement more innovations. Similarly, Naranjo-Valencia et al. (2011) found that organization dominant characteristics of hierarchy culture have positive effect on innovation. They also suggest that formal rules and procedures may foster innovation when they are balanced by other dominant characteristics. On the other hand, formalization should not become the main shared value among the members of the organization as, in that case, it can hinder innovation process.

Based on the discussions above we can argue that the relation between hierarchical organizational culture and innovation performance is not linear and needs to be further investigated. There are many other organizational factors that need to be taken into account when establishing the connections between hierarchy and innovation. For 
example, Magnusson and Martini (2008) suggest that formal control balanced with a focus on dynamism and higher risk tolerance can deliver successful results in enhancing innovation within the organization.

\subsection{Innovativeness and Rational Culture}

Cameron and Queen (2011) place organizations with rational culture to the bottom right quadrant that represents a focus on external and control-based values. Competitiveness, goal achievement and environment exchange are the dominant attributes of this type of organizational culture. Goal orientation, production and competition are the major bonding factors whereby strategic emphases lean towards competitive advantage and market superiority (Cameron and Freeman, 1985). Deshpande, Farley and Webster (1993) note that rational culture, with an emphasis on competitive advantage and market superiority, is likely to result in the best business performance. McDermott and Stock (1999) note that organizations with rational culture emphasize productivity and goal achievement, with objectives typically well-defined and external competition a primary motivating factor. In their research they have found that organizations with rational culture tend to have better competitive performance due to its emphasis on achievement and competitiveness. Gray and Hooley (2002) note that rational culture implements a corporate culture that fosters attitudes and behaviors aimed at collecting, disseminating and responding to information on actors in the external environment such as customers, competitors, market structure in ways that create value for primary and secondary stakeholders.

As rational cultures promote an external focus, organizations with rational culture tend to be consistent with the norms and values associated with creativity and innovation (Fiol \& Lyles (1985; Harrington \& Guimaraes, 2005). Similarly, Prajogo and McDermott (2011) found that rational culture is highly correlated with entrepreneurial culture. Therefore, they claim that rational culture values support both process and product innovations. In their study, O'Cass and Ngo (2007) also found similar results. They suggest that market (rational) culture and entrepreneurial culture are different yet interrelated concepts. Organizations with a dominant entrerpreneurial culture tend to pursue behaviors associated with rational culture. Because entrepreneurial culture always takes market-related factors into consideration.

However, if an organization, where rational cultural values are dominant, loses its connections with entrepreneurial values and if control-based values are heavily emphasized, we can argue that such an organization's innovative capabilities are hindered considerably.

\section{Integrated Approach to Cultural Profiles}

Although these models of organizational culture seem to be incompatible with each other, many relevant researches revealed that these different organizational cultures coexist within a single organization. Bloor and Dawson (1994) suggest that various cultural profiles can and do co-exist within a single organization. Organizations whereby only one of these culture profiles exist or heavily dominate are considered as dysfunctional. Thus, an organization representing a balanced cultural profile is regarded as desirable (Parker and Bradley, 2000). Although, a case whereby a single culture heavily dominates the organization is not desirable, certain cultures may be slightly more dominant within the successful organizations depending on several factors such as it public/private status, and the industry in which the organization operates (Howard, 1998).

In addition to above mentioned discussions, Shortell et al. (2001) suggest that multiple cultures and values coexist simultaneously and they compete for attention. This competition between the cultures leads to a situation in which one of the explained organizational cultures will be dominant. In many cases, different organizational culture in the same organization can even reinforce each other (Streefland, 1995). Newton and Jimmieson (2006) suggest that co-existence of different cultures is a characteristic of a modern organization, with some values would be more dominant than the others. Queen (1988) highlights that it would be unrealistic to expect an organization to have only one quadrant of the competing values framework. Because people and groups within the organization will have differences.

Based on the discussions above, in addition to the efforts towards explaining how each individual culture affects innovativeness, how co-existence of multiple cultures affects it is a topic worth addressing.

\section{Research Design and Methodology}

\subsection{Research Hypotheses}

This study aims to reveal the relations between different organizational cultures and innovativeness. In the literature review, different organizational cultures including team culture, entrepreneurial culture, hierarchical culture and rational culture were reviewed. Relevant research about organizational culture and innovativeness suggest that these 
variables are interrelated with each other. While certain types of organizational cultures tend to foster innovative performance, others have a potential to hinder the innovation processes within the organization. As mentioned earlier, this study focuses on the four types of organizational cultures. This classification of organizational cultures is based on the competing values framework originally developed by Quinn and Rohrbaugh (1981).

Hypotheses mentioned below were tested in order to determine the profile of the relations between different types of organizational cultures and innovativeness. Each individual organizational culture's impact on innovativeness was addressed. Our study also aims to reveal which type of organizational culture has a relatively stronger impact on innovativeness and if the impact changes when multiple organizational cultures do exist simultaneously within a single organization.

H1. Team culture orientation tends to increase the degree of innovativeness within the organization.

H2. Entrepreneurial culture orientation tends to increase the degree of innovativeness within the organization.

H3. Hierarchical culture orientation tends to decrease the degree of innovativeness within the organization.

H4. Rational culture orientation tends to increase the degree of innovativeness within the organization.

\subsection{Research Sample}

This study aims to address the employees' perspectives on how different and competing (organizational) cultural values affect the innovative performance of the organization. Therefore, subjects were drawn among the employees working at operational level in five major organizations operating in the chemicals industry in Eskisehir, Turkey.

As in the other countries, chemicals industry in Turkey is a capital and technology intensive industry. Therefore, innovation and creativity are crucial factors for the organizations in the chemicals industry. On the other hand, research and development is among the problematic issues in the industry. Total R\&D expenditures of the chemicals industry in Turkey account for only $0,03 \%$ of GDP. This percentage is very low compared to many other industries and it shows that the industry needs to invest more in research and development. According to the SWOT analysis done by the Ministry of Science, Industry and Technology (MoSIT), the major weakness of the chemicals industry in Turkey is the lack of innovation and research and development along with other factors. On the other hand, MoSIT addresses many strengths led by dynamic work force (Turkish Chemicals Industry: Strategy Report \& Action Plan, 2012).

Apart from the technical issues associated with the problems in innovativeness in the chemicals industry, we have decided to focus on the cultural factors linked with innovativeness and creativity. As mentioned in the strategy report, people in the industry play a significant role as they are the source of innovative and creative ideas. Therefore, how they perceive their organizations' culture and how they relate it with innovativeness is worth addressing.

Total number of 520 surveys were sent to seven companies operating in the chemicals industry in Eskisehir. However, two companies reported that they did not want to participate in the study. Thus, we ended up with five companies stated their approval to fill out the surveys. Total number of 406 surveys were collected from five companies. As a result of the initial check, it was found that 35 surveys were not filled out appropriately. These incomplete surveys were excluded from the analysis and we ended up with 371 surveys suitable for statistical analysis. Homogeneity is supported by drawing subjects among an identical crowd in terms of their tasks and departments.

Companies that were contacted for the research were identical in terms of the number of employees, sales figures and field of operations. Although there are many other smaller companies operating in the chemicals industry, they were not considered for this research due to compatibility issues.

\subsection{Research Instrument}

Innovativeness was measured with the scale developed by Covin and Slevin (1989). They originally developed the scale to measure the entrepreneurial orientation (EO). In their model, they suggested three dimensions to define entrepreneurial orientation including innovativeness, proactiveness and risk-taking. We have extracted five questions that measures innovativeness for this research. EO scale was adopted by many researchers as it was proved to be a reliable scale to measure the dimensions of EO including innovativeness (Lumpkin \& Dess, 1996; Tan, 1996; Frishammar \& Hörte, 2007; Holt, Rutherford \& Clohessy, 2007; Li et al., 2008).

Organizational culture was measured with an instrument developed by Cameron and Freeman (1985) based on Quinn and Rohrbaugh's (1981) competing values framework. The scale measures the relative impact of different organizational culture types - team, entrepreneurial, hierarchical and rational - that composes an organization's 
culture. All instruments in the scale consisted of five-point Likert-type scale items described by $1=$ Strongly Agree to $5=$ Strongly Disagree.

Reliability of entrepreneurial orientation scale was tested in further studies by many other scholars (Lumpkin \& Dess, 1996; Tan, 1996; Frishammar \& Hörte, 2007; Holt, Rutherford \& Clohessy, 2007; Li et al., 2008). Similarly organizational culture scale was also adopted by other scholars (Deshpande, Farley \& Webster, 1993; Leisen, Lilly \& Winsor, 2002; Lund, 2003; Berrio, 2003). Previous studies adopted entrepreneurial orientation and organization culture measures revealed that the instruments are valid, reliable and internally consistent. We also found that the scales were reliable, valid and internally consistent.

Carmines and Zeller (1979) suggest that indexes with a Cronbach's alpha value higher than .70 is considered to be acceptable. Our Cronbach's alpha value for the innovativeness scale was 0.730 and the cronbach alpha value for the organizational culture scale was 0.833 .

Scale was originally designed in English. As the study aims to measure the perceptions of employees whose language is Turkish, translated version of the instrument was used in the research. As a first step, researcher translated the instrument into Turkish. In order to increase the reliability of the translation, instrument was back-translated into English by a professional translator. Back-translated and original versions of the scale were reviewed by a colleague whose field is linguistics. Five statements were modified in order to maintain the integrity of the content. Final version of the instrument was distributed to research subjects.

\subsection{Research Findings}

Descriptive statistics and correlations among the variables used in the study are presented in Table 1. The table shows that variables used for this study are internally consistent and there are statistically significant relations between the variables. As shown in the table, we can suggest that the research subjects have made over-average statements regarding the relations between innovativeness and different organizational cultures.

Figure 3 shows the scatter plots for each individual independent variable. Scatter plots also confirm that there are statistically significant correlation between the dependent variable and independent variables.

Table 1. Correlations among the research variables

\begin{tabular}{lccccccc}
\hline Variables* & Mean & Std. Deviation & INNOV & TEAM & ENTRE & HIER & RATIO \\
\hline INNOV & 2.6652 & 0.8095 & 1,000 & & & & \\
TEAM & 2.5508 & 0.8623 &, $632^{* *}$ & 1,000 & & & \\
ENTRE & 2.5775 & 0.7385 &, $695^{* *}$ &, $720^{* *}$ & 1,000 & & \\
HIER & 3.3699 & 0.6912 &,$- 459^{* *}$ &,$- 461^{* *}$ &,$- 504 * *$ & 1,000 & \\
RATIO & 2.3935 & 0.8452 &, $698^{* *}$ &, $621^{* *}$ &, $649^{* *}$ &,$- 533^{* *}$ & 1,000 \\
\hline
\end{tabular}

**. Correlation is significant at the 0.01 level (2-tailed).

INNOV: Innovativeness

ENTRE: Entrepreneurial

HIER: Hierarchical

RATIO: Rational 

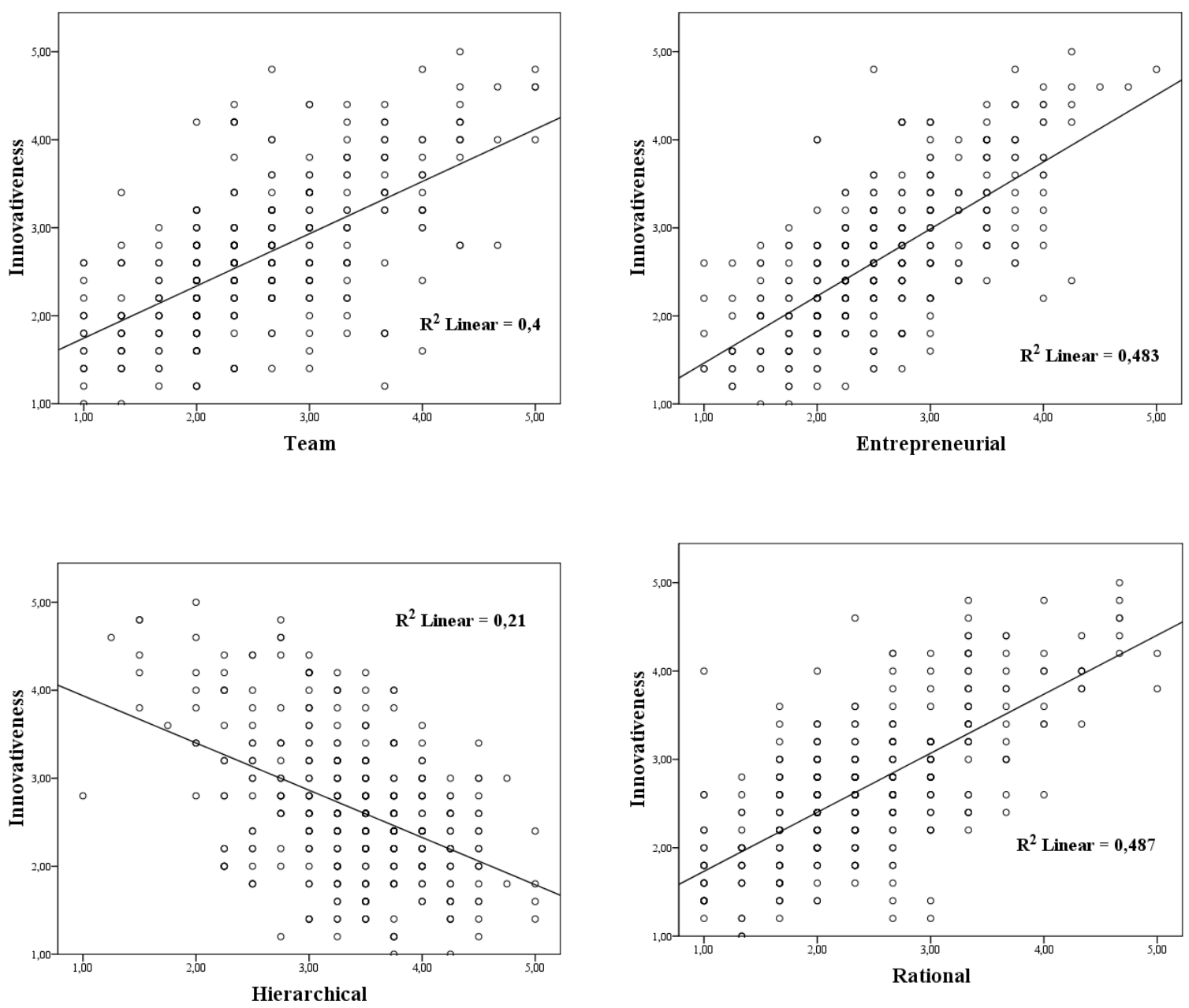

Figure 3. Scatter plots for each individual independent variable

Both statistical output and the scatter plots show that while team culture, entrepreneurial culture and rational culture are positively correlated with innovativeness, hierarchical culture has negative correlation. We can also suggest that team, entrepreneurial and rational cultures predict the dependent variable approximately at the same level. Although based on the information above we can say that there is a strong correlation between dependent and independent variables, we cannot suggest if there are causal relations between the variables.

Before we have started the regression analysis, residual scatter plot and normal P-P plot were checked to confirm if the regression model is good (Figure 4). As shown in the table, residual scatter plot shows consistent variance of error terms (homoscedasticity), and normal P-P plots of the standardized residuals also indicate normality of the error term.

Although one outlier was detected in the model, it was slightly above the accepted range. Thus, exclusion of the outlier did not change the results of the model. Based on the data provided, we suggest that the regression model is appropriate. 

Normal P-P Plot of Regression
Standardized Residual

Scatterplo

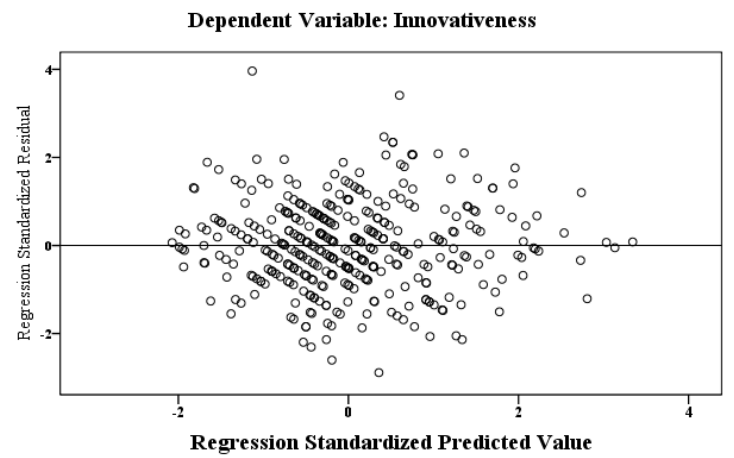

Dependent Variable: Innovativeness

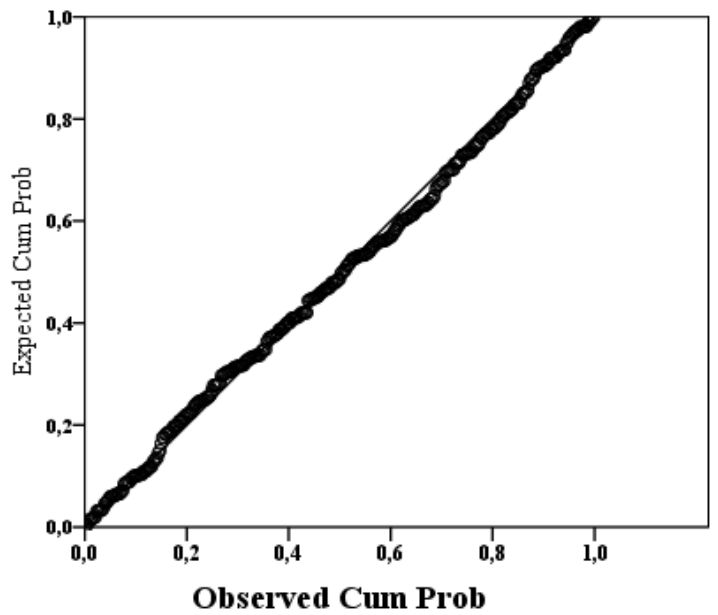

Figure 4. Residual scatter plot and normal P-P plot of regression

To test the hypothesis that the degree of innovativeness is affected by four variables, team culture, entrepreneurial culture, hierarchical culture, and rational culture, a multiple regression analysis was performed. Due to some high correlations between some independent variables - especially between entrepreneurial and team cultures multicollinearity was also tested and reported in Table 2.

According to Montgomery, Peck \& Vining (2012), if any of the variance inflation factors (VIF) exceed 5 or 10, it is an indication that the associated regression coefficients are poorly estimated because of multicollinearity. Test results for indicated that there is no multicollinearity problem between the predictor variables in the data set (Tolerance $=.44, V I F=2,28$ for team culture, Tolerance $=.40, V I F=2,47$ for entrepreneurial culture, Tolerance $=.67, V I F=$ 1,49 for hierarchical culture, and Tolerance $=.49, V I F=2,05$ for rational culture).

Table 2. Results of the multiple linear regression and multicollinearity

\begin{tabular}{lccccc}
\hline Independent Variables* & $\mathbf{S . ~ B e t a}$ & $\mathbf{t}$ & $\mathbf{p}$ & Tolerance & VIF \\
\hline Team Culture & 0,149 & 2,974 &, 003 &, 438 & 2,28 \\
Entrepreneurial Culture & 0,331 & 6,346 &, 000 &, 404 & 2,47 \\
Hierarchical Culture & $-0,021$ & $-0,526$ &, 599 &, 669 & 1,49 \\
Rational Culture & 0,379 & 7,991 &, 000 &, 488 & 2,05 \\
\hline $\mathbf{R}^{\mathbf{2}=\mathbf{5 9 4}}$ & $\mathbf{F}=\mathbf{1 3 6 , 2 4 7}$ & $\mathbf{p}=\mathbf{, 0 0 0}$ & &
\end{tabular}

As shown in the Table 2, model is statistically significant $(\mathrm{F}=136,247 ; \mathrm{p}=, 000)$. Results of the regression analysis provided confirmation for the research hypotheses except $\boldsymbol{H} \mathbf{3}$. Based on the results of the statistical analysis, we can argue that approximately 60 percent of innovative behaviors can be explained by four different organizational cultures while remaining 40 percent can be explained by other variables that we have not considered in our research.

According to hypotheses tests, we can suggest that team, entrepreneurial and rational cultures are highly correlated with innovativeness. We can also suggest that the more companies have team-based $(\beta=0,149 ; \mathrm{p}=, 003)$, entrepreneurial $(\beta=0,331 ; p=, 000)$ and rational values $(\beta=0,379$ ve $p=, 000)$, the higher innovativeness levels they tend to reach. 
On the other hand, although we have found a negative correlation between hierarchical culture and innovativeness, we cannot statistically support our hypothesis that claims hierarchical cultural values predict innovativeness within the organization $(\beta=0,021 ; p=, 599)$.

According to the results given above Hypothesis 1, Hypothesis 2 and Hypothesis 4 are accepted and Hypothesis 3 is rejected.

Table 3. Hypotheses test results

\begin{tabular}{ll}
\hline Hypotheses & Status \\
\hline $\begin{array}{l}\text { H1. Team culture orientation tends to increase the degree of innovativeness within } \\
\text { the organization. }\end{array}$ & Accepted \\
\hline $\begin{array}{l}\text { H2. Entrepreneurial culture orientation tends to increase the degree of } \\
\text { innovativeness within the organization. }\end{array}$ & Accepted \\
\hline $\begin{array}{l}\text { H3. Hierarchical culture orientation tends to decrease the degree of innovativeness } \\
\text { within the organization. }\end{array}$ & Rejected \\
\hline $\begin{array}{l}\text { H4. Rational culture orientation tends to increase the degree of innovativeness } \\
\text { within the organization. }\end{array}$ & Accepted
\end{tabular}

Considering the findings prior to the regression analysis, we were expecting to confirm all four hypotheses. However, while $\boldsymbol{H} 1, \boldsymbol{H} \mathbf{2}$ and $\boldsymbol{H} \mathbf{4}$ were confirmed in the regression model, third hypothesis $(\boldsymbol{H} 3)$ which claims that hierarchical culture orientation tends to decrease the degree of innovativeness within the organization was rejected. In order to identify the reasons why the model has rejected the third hypothesis, we have run a stepwise regression analysis by involving independent variables one by one. Simple regression results, involving the dependent variable and hierarchical culture as an independent variable, showed that hierarchical culture alone predicts statistically significant level of innovativeness. But, as we add other independent variables in the model, impact of hierarchical culture was suppressed. Especially, entrepreneurial culture and rational culture suppressed the hierarchical culture when they were added in the model.

\section{Conclusion}

Literature review regarding the relations between team culture and the level of innovativeness supports our research findings. Edmondson (1999) suggest that team climate creates a shared belief that the team and the organization is a safe environment for taking interpersonal risks and members of such a team/organizations do not fear any negative consequences when they know their initiatives will be supported even in the case of a failure. Team spirit within the organization creates an organizational climate for psychological safety that in return establishes an environment where innovative actions are encouraged and supported (Baer \& Frese, 2003). An important point that we should address is that there is a fine line between team culture and clan culture. Socialization process and internalization of values are considered within a hierarch-based control system (Ouchi \& Wilkins, 1985). There is a risk that the members of an organizations where values associated with clan culture dominate could create control systems even more powerful than the control systems introduced by the formal organization. In order to protect the informal structure, clan culture does not usually encourage risk taking and innovation (Kerr and Slocum, 1987). From this point of view, clan culture rather than a team culture could potentially hinder the innovation processes within the organization.

Second hypothesis suggesting a positive relation between entrepreneurial culture and innovativeness is also supported by the literature review. We have found that entrepreneurial culture is a strong predictor of innovativeness. Since Schumpeter (1934) has revealed his theory on economic development and built his arguments around the entrepreneurship and innovation, many research in the field found strong correlations between entrepreneurship and innovation. Zhao (2005) found that entrepreneurship and innovation are positively related to each other and these two concepts also interact to help an organization to flourish. Zhao also suggests that entrepreneurship and innovation are complementary, and a combination of is vital to organizational success and survival. Entrepreneurship and innovation are strongly correlated with each other, that even sometimes they are used interchangeably. Sternberg and Lubart (1999) suggest that creativity and innovation are closely linked with entrepreneurship. They also claim that entrepreneurship is a form of creativity. They build their arguments on the fact that the new businesses are often original and useful. At this point, we should note that entrepreneurial values are not only valid for new businesses, but also for the existing organizations. When entrepreneurial values are dominant and embedded in the culture of an organization, we can suggest that corporate entrepreneurship (intrapreneurship) would most likely to start flourishing as such an organizational culture fosters entrepreneurial and innovative values. 
As previously mentioned, third hypothesis of our research was rejected. Although we have found a strong negative correlation between hierarchical values and innovativeness, we could not find any causality between these variables. We think that this was a result of suppression of "hierarchical culture" variable by other variables. In the literature review, we have also found that the relations between hierarchical values and innovativeness are paradoxical. While a stream of research claim that hierarchical values hinder innovativeness (Rickards, 1985; Caruana, 1998; Barringer \& Bluedorn, 1999), others claim that hierarchical values can also support innovative processes under certain conditions (Ayers et al., 1997; Ghoshal \& Bartlett, 1998). Bonner et al. (2002) suggests that effective implementation of hierarchy-related organizational practices is important for managing innovative processes. Based on the results we have obtained in our research, we suggest that team-based, entrepreneurial and rational values are better predictors for innovativeness. However, this interpretation is based on the data we have collected from our research subjects and needs to be further investigated by implementing other research methods, using different scales, expanding sample size or even collecting data from different sectors.

Finally, our fourth hypothesis suggesting that there is a positive relation between rational culture and innovativeness was also supported. According to our findings, rational cultural values are strong predictors of innovativeness. Our findings are also supported by the literature review. Igo and Skitmore (2006) suggest that an organization with dominant rational cultural values tends to be result oriented and concentrate on getting the job done. Organization and its members value competitiveness, aggressiveness, personal initiative, diligence and perfectionism. According to Yardley and Neal (2007) organizations with market culture maintain strong relations with their stakeholders. Profitability, bottom-line results, strength in market niches, stretch targets and a secure customer base, are primary objectives of the organization while the core values are competitiveness and productivity. Such an organization would most likely to need innovative skills to obtain and maintain the competitive edge that it seeks. External focus of rational culture requires organization to constantly scan its environment and respond with innovative products/services to stay competitive. However, control-based values embedded in this cultural profile draw a fine line between rational organizational culture and hierarchical organizational culture. Organizations falling in this quadrant of the model should be very careful in governing their operations. Because, there is a risk of losing responsiveness if the organization falls in the trap of creating ineffective and heavily controlled processes, procedures, rules and regulations.

\section{References}

Abok, A., Waititu, A., Gakure, R., \& Ragui, M. (2013). Culture's role in the implementation of strategic plans in non-governmental organizations in Kenya. Prime Journal of Social Science, 2(4), 291-295.

Amabile, T.M., Conti, R., Coon, H., Lazenby, J., \& Herron, M. (1996). Assessing the work environment for creativity. Academy of Management Journal, 39(5), 1154-1184. http://dx.doi.org/10.2307/256995

Audretsch, D.B., \& Acs, Z.J. (1991). Innovation and size at the firm level. Southern Economic Journal, 57(3), 739-744. http://dx.doi.org/10.2307/1059787

Ayers, D., Dahlstrom, R., \& Skinner, Birkinshaw, J. (1997). Entrepreneurship in multinational corporations: The characteristics of subsidiary initiatives. Strategic Management Journal, 18(3), 207-229. http://dx.doi.org/10.1002/(SICI)1097-0266(199703)18:3<207::AID-SMJ864>3.0.CO;2-Q

Baer, M., \& Frese, M. (2003). Innovation is not enough: Climates for initiative and psychological safety, process innovations, and firm performance. Journal of Organizational Behavior, 24(1), 45-68. http://dx.doi.org/10.1002/job.179

Barker, J.R. (1993). Tightening the iron cage: Concertive control in self-managing teams. Administrative Science Quarterly, 38(3), 408-437. http://dx.doi.org/10.2307/2393374

Barringer, B.R., \& Bluedorn, A.C. (1999). The relationship between corporate entrepreneurship and strategic $\begin{array}{lllll}\text { management. Strategic } & \text { Management } & \text { Journal, } & \text { 421-444. }\end{array}$ http://dx.doi.org/10.1002/(SICI)1097-0266(199905)20:5<421::AID-SMJ30>3.0.CO;2-O

Bartunek, J.M., \& Moch, M.K. (1987). First-order, second-order, and third-order change and organization development interventions: A cognitive approach. The Journal of Applied Behavioral Science, 23(4), 483-500. http://dx.doi.org/10.1177/002188638702300404

Berrio, A.A. (2003). An organizational culture assessment using the competing values framework: A profile of Ohio State University Extension. Age, 2(699), 1-052. 
Bonner, J. M., Ruekert, R. W., \& Walker, O. C. (2002). Upper management control of new product development projects and project performance. Journal of Product Innovation Management, 19(3), 233-245. http://dx.doi.org/10.1111/1540-5885.1930233

Burns, T., \& Stalker, G.M. (1961). The Management of Innovation. Travistock Publications.

Cameron, K.S., \& Freeman, S.J. (1985). Cultural congruence, strength, and type: Relationships to effectiveness. School of Business Administration, University of Michigan.

Cameron, K.S., \& Freeman, S.J. (1991). Cultural congruence, strength, and type: Relationships to effectiveness. Research in Organizational Change and Development, 5(1), 23-58

Cameron, K.S., \& Quinn, R.E. (2011). Diagnosing and changing organizational culture: Based on the competing values framework. Jossey-Bass.

Carmines, E., \& Zeller, R. (1979). Reliability and validity assessment. Beverly Hills, CA: Sage Publications.

Caruana, A., Morris, M.H., \& Vella, A.J. (1998). The effect of centralization and formalization on entrepreneurship in export firms. Journal of Small Business Management, 36(1), 16-29.

Claver, E. et al. (1998). Organizational culture for innovation and new technological behavior. The Journal of High Technology Management Research, 9(1), 55-68. http://dx.doi.org/10.1016/1047-8310(88)90005-3

Constant, D., Kiesler, S., \& Sproull, L. (1994). What's mine is ours, or is it? A study of attitudes about information sharing. Information Systems Research, 5(4), 400-421. http://dx.doi.org/10.1287/isre.5.4.400

Covin, J.G., \& Miles, M.P. (1999). Corporate entrepreneurship and the pursuit of competitive advantage. Entrepreneurship: Theory \& Practice, 23(3), 47-63.

Covin, J.G., \& Slevin, D.P. (1989). Strategic management of small firms in hostile and benign environments. Strategic Management Journal, 10(1), 75-87. http://dx.doi.org/10.1002/smj.4250100107

Damanpour, F. (1991). Organizational innovation: A meta-analysis of effects of determinants and moderators. The Academy of Management Journal, 34(3), 555-590. http://dx.doi.org/10.2307/256406

Dastmalchian, A., Lee, S., \& Ng, I. (2000). The interplay between organizational and national cultures: a comparison of organizational practices in Canada and South Korea using the Competing Values Framework. International Journal of Human Resource Management, 11(2), 388-412. http://dx.doi.org/10.1080/095851900339927

Day, G.S. (2002). Marketing and the CEO's growth imperative. In meeting of the Marketing Science Institute Trustees, April, 25-26.

Demirci, A.E. (2013). In pursuit of corporate entrepreneurship: How employees perceive the role of formalization and centralization. Journal of Management Research, 5(3), 115-133. http://dx.doi.org/10.5296/jmr.v5i3.3597

Denison, D. R. (1990). Corporate culture and organizational effectiveness. New York: Wiley.

Denison, D.R., \& Mishra, A.K. (1995). Toward a theory of organizational culture and effectiveness. Organization science, 6(2), 204-223. http://dx.doi.org/10.1287/orsc.6.2.204

Deshpande, R., \& Farley, J.U. (1999). Corporate culture and market orientation: Comparing Indian and Japanese firms. Journal of International Marketing, 7(4), 111-127.

Deshpande, R., Farley, J.U., \& Webster Jr, F.E. (1993). Corporate culture, customer orientation, and innovativeness in Japanese firms: a quadrad analysis. The Journal of Marketing, 57(1), 23-37. http://dx.doi.org/10.2307/1252055

Edmondson, A. (1999). Psychological safety and learning behavior in work teams. Administrative Science Quarterly, 44(2), 350-383. http://dx.doi.org/10.2307/2666999

Fiol, C.M., \& Lyles, M.A. (1985). Organizational learning. Academy of Management Review, 10(4), 803-813.

Foster-Fishman, P.G., \& Keys, C.B. (1997). The person/environment dynamics of employee empowerment: An organizational culture analysis. American Journal of Community Psychology, 25(3), 345-369. http://dx.doi.org/10.1023/A:1024628711026

Frishammar, J., \& Åke Hörte, S. (2007). The role of market orientation and entrepreneurial orientation for new product development performance in manufacturing firms. Technology Analysis \& Strategic Management, 19(6), 765-788. http://dx.doi.org/10.1080/09537320701711231 
Ghoshal, S., \& Bartlett, C.A. (1988). Creation, adoption, and diffusion of innovations by subsidiaries of multinational corporations. Journal of International Business Studies, 19(3), 365-388. http://dx.doi.org/10.1057/palgrave.jibs.8490388

Gray, B.J., \& Hooley, G.J. (2002). Guest editorial: market orientation and service firm performance-a research agenda. European Journal of marketing, 36(9/10), 980-989. http://dx.doi.org/10.1108/03090560210437280

Gregory, B. T., Harris, S. G., Armenakis, A. A., \& Shook, C. L. (2009). Organizational culture and effectiveness: A study of values, attitudes, and organizational outcomes. Journal of Business Research, 62(7), 673-679. http://dx.doi.org/10.1016/j.jbusres.2008.05.021

Harrington, S.J., \& Guimaraes, T. (2005). Corporate culture, absorptive capacity and IT success. Information and Organization, 15(1), 39-63. http://dx.doi.org/10.1016/j.infoandorg.2004.10.002

Hartmann, A. (2006). The role of organizational culture in motivating innovative behaviour in construction firms. Construction Innovation: Information, Process, Management, 6(3), 159-172. http://dx.doi.org/10.1108/14714170610710712

Hise, R.T., O'Neal, L., Parasuraman, A., \& McNeal, J.U. (1990). Marketing/R\&D interaction in new product development: implications for new product success rates. Journal of Product Innovation Management, 7(2), 142-155. http://dx.doi.org/10.1016/0737-6782(90)90056-K

Hoegl, M., \& Proserpio, L. (2004). Team member proximity and teamwork in innovative projects. Research Policy, 33(8), 1153-1165. http://dx.doi.org/10.1016/j.respol.2004.06.005

Holt, D.T., Rutherford, M.W., \& Clohessy, G.R. (2007). Corporate entrepreneurship: an empirical look at individual characteristics, context, and process. Journal of Leadership \& Organizational Studies, 13(4), 40-54. http://dx.doi.org/10.1177/10717919070130040701

Howard, L.W. (1998). Validating the competing values model as a representation of organizational cultures. International Journal of Organizational Analysis, 6(3), 231-250. http://dx.doi.org/10.1108/eb028886

Hurley, R.F., \& Hult, G.T.M. (1998). Innovation, market orientation, and organizational learning: an integration and empirical examination. The Journal of Marketing, 62(3), 42-54. http://dx.doi.org/10.2307/1251742

Igo, T., \& Skitmore, M. (2006). Diagnosing the organizational culture of an Australian engineering consultancy using the competing values framework. Construction Innovation: Information, Process, Management, 6(2), 121-139.

Jun, S. \& Shin, Y. (1995). An empirical study on the behaviour effectiveness by fitness of organizational culture and leadership. Korean Management Review, 24(4), 153-86.

Kanter, R. (1996). When a thousand flowers bloom: structural, collective, and social conditions for innovation in organizations. Knowledge Management and Organisational Design, 93-131. http://dx.doi.org/10.1016/B978-0-7506-9749-1.50010-7

Katzenbach, J.R., \& Smith, D.K. (1992). The wisdom of teams. Harvard Business School Press.

Kerr, J., \& Slocum Jr, J.W. (1987). Managing corporate culture through reward systems. The Academy of Management Executive (1987-1989), 1(2), 99-107. http://dx.doi.org/10.5465/AME.1987.4275817

Lemon, M. \& Sahota, P.S. (2004). Organizational culture as a knowledge repository for increased innovative capacity. Technovation, 24, 483-498. http://dx.doi.org/10.1016/S0166-4972(02)00102-5

Li, Y., Zhao, Y., Tan, J., \& Liu, Y. (2008). Moderating Effects of Entrepreneurial Orientation on Market Orientation-Performance Linkage: Evidence from Chinese Small Firms. Journal of Small Business Management, 46(1), 113-133. http://dx.doi.org/10.1111/j.1540-627X.2007.00235.x

Lumpkin, G.T., \& Dess, G.G. (1996). Clarifying the entrepreneurial orientation construct and linking it to performance. Academy of Management Review, 21(1), 135-172.

Lund, D.B. (2003). Organizational culture and job satisfaction. Journal of Business \& Industrial Marketing, 18(3), 219-236. http://dx.doi.org/10.1108/0885862031047313

Magnusson, M., \& Martini, A. (2008). Dual organisational capabilities: from theory to practice-the next challenge for continuous innovation. International Journal of Technology Management, 42(1), 1-19. http://dx.doi.org/10.1504/IJTM.2008.018073 
Malagueño, R., \& Bisbe, J. (2010). The role of management accounting and control systems as antecedents of organizational creativity and innovation capabilities. Available at SSRN 1720989. http://dx.doi.org/10.2139/ssrn.1720989

Martins, E.C., \& Terblanche, F. (2003). Building organisational culture that stimulates creativity and innovation. European Journal of Innovation Management, 6(1), 64-74. http://dx.doi.org/10.1108/14601060310456337

McDermott, C.M., \& Stock, G.N. (1999). Organizational culture and advanced manufacturing technology implementation. Journal of Operations Management, 17(5), 521-533. http://dx.doi.org/10.1016/S0272-6963(99)00008-X

McGuire, S.J.J. (2003). Entrepreneurial organizational culture: Construct definition and instrument development and validation. Ph.D. Dissertation, The George Washington University, Washington, DC.

Montgomery, D.C., Peck, E.A., \& Vining, G.G. (2012). Introduction to linear regression analysis (Vol. 821). Wiley.

Morariu, A., Serghiuţă, R., \& Chaşovschi, C. (2009). The impact of cultural and motivational environment within an organisation upon human resources. The USV Annals of Economics and Public Administration, 9(1), 163-169.

Naranjo-Valencia, J.C., Jiménez-Jiménez, D., \& Sanz-Valle, R. (2011). Innovation or imitation? The role of organizational culture. Management Decision, 49(1), 55-72. http://dx.doi.org/10.1108/00251741111094437

Newton, C.J., \& Jimmieson, N.L. (2006). A qualitative exploration of organizational culture and workplace stressors: A competing values approach.

O'Cass, A., \& Ngo, L.V. (2007). Market orientation versus innovative culture: two routes to superior brand performance. European Journal of Marketing, 41(7/8), 868-887. http://dx.doi.org/10.1108/03090560710752438

Ouchi, W.G., \& Wilkins, A.L. (1985). Organizational culture. Annual Review of Sociology, 11, 457-483. http://dx.doi.org/10.1146/annurev.so.11.080185.002325

Ozdemir, A.A., \& Demirci, A.E. (2012). Impact of Social Capital on Radical Innovation Efforts of the Organizations: A Case in the Aviation Industry. Ege Academic Review, 12(1), 55-68.

Parker, R., \& Bradley, L. (2000). Organisational culture in the public sector: evidence from six organisations. International Journal of Public Sector Management, 13(2), 125-141. http://dx.doi.org/10.1108/09513550010338773

Porter, M.E. (1991). La ventaja competitiva de las naciones. Barcelona: Plaza \& Janes.

Prajogo, D.I., \& McDermott, C.M. (2011). The relationship between multidimensional organizational culture and performance. International Journal of Operations \& Production Management, 31(7), 712-735. http://dx.doi.org/10.1108/01443571111144823

Quinn, R. E. (1988). Beyond rational management: Mastering the Paradoxes and Competing Demands of High Performance. Jossey-Bass.

Quinn, R.E., \& Rohrbaugh, J. (1981). A competing values approach to organizational effectiveness. Public Productivity Review, 5(2), 122-140. http://dx.doi.org/10.2307/3380029

Quinn, R.E., \& Rohrbaugh, J. (1983). A spatial model of effectiveness criteria: towards a competing values approach to organizational analysis. Management Science, 29(3), 363-377. http://dx.doi.org/10.1287/mnsc.29.3.363

Read, W.H. (1996). Managing the knowledge-based organization: five principles every manager can use. Technology Analysis \& Strategic Management, 8(3), 223-233. http://dx.doi.org/10.1080/09537329608524247

Rickards, T. (1985). Stimulating innovation: A systems approach. London, Pinter.

Schein, E. H. (1985). Organisational culture and leadership: A dynamic view. San Francisco.

Schumpeter, J.A. (1934). The theory of economic development. Cambridge: Harvard University Press.

Sethi, R., Smith, D.C., \& Park, C.W. (2001). Cross-functional product development teams, creativity, and the innovativeness of new consumer products. Journal of Marketing Research, 73-85. http://dx.doi.org/10.1509/jmkr.38.1.73.18833

Shane, S. (1993). Cultural influences on national rates of innovation. Journal of Business Venturing, 8(1), 59-73. http://dx.doi.org/10.1016/0883-9026(93)90011-S 
Shortell, S.M. et al. (2001). Implementing evidence-based medicine: the role of market pressures, compensation incentives, and culture in physician organizations. Medical Care, 39(7), 162-178.

Siegel, D.S., Waldman, D., \& Link, A. (2003). Assessing the impact of organizational practices on the relative productivity of university technology transfer offices: an exploratory study. Research Policy, 32(1), 27-48. http://dx.doi.org/10.1016/S0048-7333(01)00196-2

Sternberg, R.J., \& Lubart, T.I. (1999). The concept of creativity: Prospects and paradigms. Handbook of Creativity, 1 , 3-15.

Streefland, P.H. (1995). Enhancing coverage and sustainability of vaccination programs: an explanatory framework with special reference to India. Social Science \& Medicine, 41(5), 647-656. http://dx.doi.org/10.1016/0277-9536(95)00036-7

Tan, J. (1996). Characteristics of regulatory environment and impact on entrepreneurial strategic orientations: an empirical study of Chinese private entrepreneurs. Academy of Management Proceedings, 1996(1), 106-110.

Tödtling, F., Lehner, P., \& Kaufmann, A. (2009). Do different types of innovation rely on specific kinds of knowledge interactions?. Technovation, 29(1), 59-71. http://dx.doi.org/10.1016/j.technovation.2008.05.002

Turkish Ministry of Science, Industry and Technology (2012). Chemicals Industry: Strategy Report \& Action Plan, Ankara.

Tushman, M.L., Tushman, M., \& O'Reilly, C.A. (2006). Winning through innovation: A practical guide to leading organizational change and renewal. Harvard Business School Press.

Tylecote, A. (1996). Cultural differences affecting technological innovation in Western Europe. European Journal of Work and Organizational Psychology, 5(1), 137-147. http://dx.doi.org/10.1080/13594329608414847

Van de Ven, A.H. (1976). On the nature, formation, and maintenance of relations among organizations. Academy of Management Review, 1(4), 24-36. http://dx.doi.org/10.2307/257722

Wildavsky, A., \& Dake, K. (1990). Theories of risk perception: Who fears what and why? Daedalus, 119(4), 41-60.

Yardley, I., \& Neal, D.J. (2007). Understanding the leadership and culture dynamic within a military context: Applying theory to an operational and business context. Defence Studies, 7(1), 21-41. http://dx.doi.org/10.1080/14702430601135560

Zhao, F. (2005). Exploring the synergy between entrepreneurship and innovation. International Journal of Entrepreneurial Behaviour \& Research, 11(1), 25-41. http://dx.doi.org/10.1108/13552550510580825 